AKTIVITY NA ROZVOJ

GEOMETRICKÝCH PREDSTÁV

ŽIAKOV MLADŠIEHO ŠKOLSKÉHO VEKU

\title{
ACTIVITIES FOR THE DEVELOPMENT OF GEOMETRIC CONCEPTIONS OF PUPILS IN PRIMARY EDUCATION
}

\author{
Kitti Páleníková, Mária Bugárová \\ ${ }^{1}$ Katedra matematiky, Fakulta prírodných vied, Univerzita Konštantína Filozofa v Nitre (Slovenská republika)
}

\author{
OJPPE 2(1) - Recenzované články/Reviewed Papers \\ Publikováno/Published 20. 12. 2018 \\ DOI: 10.21062/ujep/227.2018/a/2533-7106/OJPPE/2/1/23
}

\begin{abstract}
Abstrakt
Geometrické poznatky sú nepochybne vel'mi dôležité pre každého človeka. Pri ich nadobúdaní v školskom prostredí môžeme začlenit’ do vyučovania rôzne úlohy a aktivity, ktoré žiakov zaujmú najmä hrovou formou. $\checkmark$ príspevku uvádzame návrhy aktivít zameraných na rozlišovanie, pomenovanie a kreslenie rovinných a priestorových útvarov. Niektoré z aktivít sme realizovali so žiakmi prvého stupňa základnej školy. Popisujeme výsledky získané pozorovaním žiakov pri práci a analýzou ich činnosti.
\end{abstract}

Kl'účové slová: geometrické predstavy, geometrické tvary, primárne vzdelávanie.

\section{Abstract}

Geometric knowledge is clearly very important for everyone. When acquiring them in the school environment, we can integrate various tasks and activities into the classroom, which are interesting for pupils due to playful form. In this article we present proposals of activities focused on distinguishing, naming and drawing of planar and spatial shapes. We realised some of the activities with primary school pupils. We describe the results obtained by observing pupils during work and analysing their products.

Keywords: geometric conceptions, geometric shapes, primary education.

\section{ÚVOD}

Nakol'ko sa človek od narodenia pohybuje v priestore, potrebu geometrie a geometrických predstáv vníma každý z nás. Vel'mi dôležité je tiež, aby si vedel predstavovat' obraz obklopujúcich predmetov a javov, ktorým sú pocity, vnemy, pojmy či myšlienky. Schopnost' priestorovej predstavivosti je dôležitá, miestami až nevyhnutná pre mnoho oblastí l'udského života, akými sú napr. architektúra, učitel'stvo, dizajnérstvo, matematika či lekárstvo. Prvé úvahy týkajúce sa priestorových problémov vznikli už v dávnej minulosti vychádzajúce z praktických činností. Zhotovovanie náročných stavebných prác, rozličných nástrojov, zbraní, odevov, stavba obydlí, vozov a lodí bolo umožnené vedomost́ami z oblasti stereometrie. Pozorovanie hviezdnej oblohy bolo prínosné pre vznik geometrických poznatkov o guli, na základe pohybu planét dokázali vytvárat' kalendár a definovat́ miesta na Zemi. Teda skúsenosti získané mnohonásobnou opakovanou súčinnostou rúk, očí a umu boli základom poznania geometrie. Takáto istá činnost' je východiskom geometrického poznania i v ontogenéze - hry s kockami, šitie šiat pre bábiky, orientácia na sídlisku - to všetko sú počiatky budúcich znalostí. Základná škola je dôležitým miestom, kde sa u diet́at́a rozvíja jeho osobnost' z hladiska osobnostnej, telesnej, spoločenskej či emocionálnej stránky. Ked’že u dietatata stále zohráva významnú úlohu hra, preto je dôležité, aby sa učebné činnosti dopíňali rôznymi hrovými aktivitami či didaktickými hrami. Prostredníctvom takýchto aktivít žiak ani nepostrehne, že sa učí, rozvíja sa jeho predstavivost', tvorivost' a myslenie. Súhlasíme so Šmahovskou (2014), že v procese vzdelávania zohráva významnú úlohu schopnost' žiaka predstavit' si geometrické útvary a súvislosti medzi nimi. Zaradené nenáročné úlohy zamerané na rozvoj geometrických predstáv na hodiny 
geometrie na prvom stupni základnej školy pomáhajú pri rozvíjaní schopnosti pozorovat', všímat' si podrobnosti, percipovat' rozmer a polohu útvarov, s ktorými žiak narába.

\section{TEORETICKÉ VÝCHODISKÁ}

\section{Mladší školský vek}

Po dosiahnutí šiestich rokov života každého dietatáa je vel'mi významným životným medzníkom práve vstup do školy. Doteraz prevládajúca činnost', ktorá vo väčšej miere bola hra, je dopíñaná a často nahrádzaná povinnostáami a prácou. Tie vyžadujú zvýšené nároky na dodržanie zásad, na vôlové konanie nevyhnutné na pokračovanie $v$ činnostiach, na odklad okamžitého uspokojenia potrieb. Ked'že najprirodzenejšou činnostou pre dietáa je hra, je možné zahrnút ju do výchovno-vzdelávacieho procesu. $V$ tom prípade plní viac dôležitých úloh. Z nich pokladáme za najvýznamnejšiu úlohu motivačný prostriedok, ktorá sa podiela na aktivite žiakov rôznej úrovne schopností (Verkinová, 1998). Podla Čápa (1980) je pre dietáa vstup do školy akýmsi znakom vyspelosti, je dokladom toho, že sa priblížilo $k$ vytúženému ciel'u byt' vel'kým, dospelým. Škola prináša dietatúu nové, učebné činnosti, kladie vyššie požiadavky na poznávacie procesy, pamät', pozornost', vytrvalost' a sebaovládanie a rozvíja tieto procesy, vlastnosti a stavy. Vedie dietáa k osvojovaniu mnohých vedomostí a podnecuje jeho záujmy. Obdobie mladšieho školského veku je podla Jurišovej (2013) obdobím, kedy sa deti orientujú na svojich rovesníkov a na zdokonal'ovanie ich výkonu v sociálnych, fyzických či intelektových schopnostiach, zručnostiach. V tomto období sa deti neustále sociálne porovnávajú, hodnotia svoje schopnosti so schopnostáami iných detí rovnakého veku. Je to čas, kedy je diet́a najviac pripravené učit' sa dychtivo a rýchlo. Pre diet́a je vel'mi nebezpečné zlyhanie, alebo pocit zlyhania v plnení úloh, ktoré dostáva od školy a domáceho prostredia. Dôsledkom toho môže nastat́ vznik pocitu menejcennosti. Jakabčic (2002) uvádza, že vobdobí mladšieho školského veku výrazne narastá fyzická výkonnost' dietatáa, je ustavične v pohybe, ale nie je schopné ešte dobre hospodárit' so svojimi silami, môže sa rýchlo vyčerpat'. V oblasti zmyslového vnímania si diet́a všíma aj podrobnosti javov, dokáže rozdelit celok na časti a následne ich správne spojit. Vo vnímaní sa častejšie uplatňuje jeho skúsenost', vnímanie sa stáva cielavedomou činnostou, čo predstavuje pozorovanie. Zvyšuje sa rozlišovacia schopnost', čo sa prejavuje v rozlišovaní stále menšieho rozdielu vintenzite dvoch podnetov. $\checkmark$ procese predstavivosti spontánnost' vystrieda zámerné vybavovanie predstáv. $V$ mladšom školskom veku majú deti schopnost' vybavit' si v pamäti konkrétne a podrobné predstavy. Na začiatku školskej dochádzky je ešte v prevahe mechanický spôsob učenia sa (vštepovania do pamäti). Postupným vývinom rozumových schopností je diet́a schopné triedit' pamätový materiál a chápat jeho zmysel, rýchlejšie vštepovat' a kvalitnejšie ho podržat' v pamäti. Podl'a Jurča (1964) je rozumový vývin detí možný riadit'. Z hladiska záujmov spoločnosti a jednotlivca možno dosahovat' výchovným pôsobením dokonalejší rozumový vývin ako živelným priebehom. Pre to je potrebné rozvíjat všeobecnejšie psychické vlastnosti, t. j. schopnosti, na základe ktorých môže jedinec zvládnut' rôzne nové životné situácie. Teda je dôležité navrhnút úlohy, ktoré si má dieta rôznych vekových stupňov osvojit a ktoré sa má naučit riešit'.

\section{Geometrické predstavy}

Podl'a Sternberga (2002, In Šedivý, O., 2005) sú predstavy mentálne reprezentácie predmetov, udalostí, javov a iných vecí, ktoré vokamihu reprezentácie nie sú vnímané zmyslami. Predstavy stoja na prechode od konkrétneho k abstraktnému poznávaniu a podl'a Popperovej (1964) sú súčasne spojivom medzi abstraktným myslením a praktickou činnostou. A práve preto treba $v$ učebnom procese dbat' na to, aby si žiaci utvárali bohaté a správne predstavy. Boroš (2002) chápe predstavivost' a obrazotvornost' ako procesy, v ktorých sa výrazne javí ludský charakter činnosti. Vysvetl'uje, že predstavy nevznikajú samy od seba, ale v skutočnom živote. Predmet a spôsob predstavovania závisí od objektívnych podmienok, od životných potrieb a záujmov človeka. Ďalej definuje predstavy ako obrazy predmetov, vecí či javov, ktoré človek vurčitom momente nevníma. Predstava je teda reprodukovaným predmetom, ktorý je založený na minulej skúsenosti. Predstavy sa vytvárajú najmä v pracovnej činnosti, a preto sú nielen predpokladom, ale taktiež výsledkom rozvoja rozmanitých tvorivých aktivít človeka.

Geometrické predstavy sú výsledkom geometrickej predstavivosti, ktorú Molnár (2009) chápe ako schopnost:

$>$ vnímat' geometrický útvar s jeho vel'kost'ou a polohou v priestore,

> predstavit si útvar v inej polohe, s inými rozmermi, štruktúry a pod.,

> znázornit telesá v rovine, prípadne podla slovného popisu,

$>z$ rovinného obrazu modelovat priestorový útvar. 
Vymedzenie sekvenčných a hierarchických úrovní (hladín) poznávacieho procesu definovali osobitne pre oblast' geometrie holandskí učitelia matematiky Pierre van Hiele a jeho manželka Dina van Hiele-Geldof. Na základe pozorovania svojich tried uviedli, že poznávací proces možno rozložit do piatich úrovní, pričom v každej úrovni je rozpoznatel'ný spôsob vnímania geometrických pojmov: úroveň vizualizácie, úroveň analýzy (opisu), úroveň neformálnej dedukcie (abstrakcie), úroveň dedukcie a úroveň axiomatizácie. Popis jednotlivých úrovní [14]:

\section{Úroveň vizualizácie}

Osoba na tejto úrovni vie rozpoznat' tvary na základe celkového vzhl'adu, nie však vzhl'adom na vlastnosti. Napríklad žiaci budú mysliet́ na tvar vzhl'adom na to, na čo sa podobajú, napr. obdľžnik vyzerá ako dvere a trojuholník ako klobúk klauna. Žiak nemusí byt' schopný rozpoznat́ tvar, ak je pootočený.

\section{Úroveň analýzy (opisu)}

Žiaci sa začínajú učit' a identifikovat časti obrazcov, rovnako ako vidiet' obrazce v skupine tvarov. Vedia popísat' vlastnosti, tvar a sú schopní pochopit, že tvary v skupine majú rovnaké vlastnosti. Žiak na tejto úrovni vie, že rovnobežníky majú protilahlé strany, ktoré sú rovnobežné a je schopný ich podl'a toho zoskupovat'.

\section{Úroveň neformálnej dedukcie (abstrakcie)}

Žiak na tejto úrovni začne rozpoznávat' vztáah medzi vlastnostami tvarov. Je tiež schopný podielat' sa a pochopit' neformálne deduktívne diskusie o tvaroch a ich rozdielnych vlastnostiach.

\section{Úroveň dedukcie}

Na tejto úrovni sú žiaci schopní zložitejších geometrických pojmov. Môžu uvažovat o súvisiacich vlastnostiach, ako aj o vztáahoch medzi axiómami, vetami, postulátmi a definíciami. Žiaci by mali byt' schopní "pracovat' s abstraktnými výrokmi o geometrických vlastnostiach a robit závery viac o logike ako o intuícii".

\section{Úroveň axiomatizácie}

Nakoniec, študenti dosiahnu poslednú úroveň učenia geometrického uvažovania. Aj pri absencii konkrétnych príkladov by mali byt' schopní porovnávat' geometrické výsledky v rôznych axiomatických systémoch. $V$ podstate uvidia geometriu v abstraktnej podobe. Väčšinou je to úroveň študentov vysokých škôl a ako oni premýšl'ajú o geometrii.

Žiaci mladšieho školského veku sú obvykle na prvej úrovni v 1. a 2. ročníku (vek 5 až 7 rokov), potom prechádzajú na úroveň druhú - obvykle 3. až 5. ročník základnej školy (vek 7 až 10 rokov).

\section{Geometrické tvary v Štátnom vzdelávacom programe pre primárne vzdelávanie}

Nakol'ko sme sa v navrhovaných aktivitách zamerali na geometrické tvary, preskúmali sme aj obsahový a výkonový štandard štátneho vzdelávacieho programu.

Tab. 1 Geometrické tvary v učive matematiky na prvom stupni základných škôl podl'a ŠVP (2015)

\begin{tabular}{|c|c|c|}
\hline Ročník & Obsahový štandard & Výkonový štandard \\
\hline $\begin{array}{l}\text { 兰 } \\
\text {, } \\
\text { - } \\
\end{array}$ & $\begin{array}{l}\text { rovinné geometrické útvary: krivá čiara, rovná } \\
\text { čiara, otvorená a uzavretá čiara, kruh, } \\
\text { štvorec, trojuholník, obdížnik } \\
\text { priestorové geometrické útvary: kocka, valec, } \\
\text { gul'a }\end{array}$ & $\begin{array}{l}\text { rozlíšit', pomenovat', nakreslit' rovinné } \\
\text { geometrické útvary, } \\
\text { rozlišit' a pomenovat' priestorové geometrické } \\
\text { útvary, } \\
\text { umiestnit' (dokreslit') rovinné a priestorové } \\
\text { geometrické útvary podl'a pokynov, }\end{array}$ \\
\hline 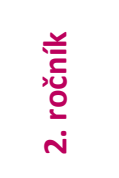 & $\begin{array}{l}\text { pomenovanie mnohouholníkov: trojuholník, } \\
\text { štvoruholník, ... } \\
\text { strana a vrchol rovinného geometrického } \\
\text { útvaru }\end{array}$ & $\begin{array}{l}\text { identifikovat' a pomenovat' mnohouholníky, } \\
\text { identifikovat' strany a vrcholy rovinných } \\
\text { geometrických útvarov, }\end{array}$ \\
\hline 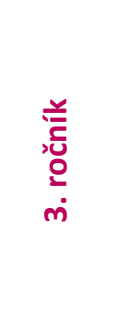 & $\begin{array}{l}\text { rysovanie štvorca a obdĺžnika v štvorcovej } \\
\text { sieti } \\
\text { označovanie vrcholov štvorca a obdĺžnika } \\
\text { vel'kým tlačeným písmenom } \\
\text { zväčšenie a zmenšenie rovinných útvarov } \\
\text { v štvorcovej sieti } \\
\text { vrchol, hrana a stena kocky }\end{array}$ & $\begin{array}{l}\text { narysovat' rovinné útvary v štvorcovej sieti } \\
\text { a označit' ich vrcholy vel'kým tlačeným } \\
\text { písmenom, } \\
\text { zväčšit' a zmenšit' rovinné útvary v štvorcovej } \\
\text { sieti (štvorec, obdĺžnik), } \\
\text { identifikovat' steny, hrany a vrcholy kocky, }\end{array}$ \\
\hline
\end{tabular}




\begin{tabular}{|c|c|c|}
\hline 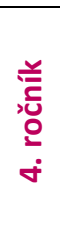 & $\begin{array}{l}\text { mnohouholník, označenie mnohouholníka } \\
(A B C D, A B C D E, . . .) \\
\text { vrchol a strana trojuholníka, štvorca, } \\
\text { obdížnika, štvoruholníka, pätúuholníka, }\end{array}$ & $\begin{array}{l}\text { identifikovat' a pomenovat' mnohouholník } \\
\text { (štvoruholník, pättuholník, ...), } \\
\text { vymenovat' vrcholy a strany mnohouholníka } \\
\text { (trojuholníka, štvorca a obdížnika, } \\
\text { štvoruholníka, pät'uholníka, ...) }\end{array}$ \\
\hline $\begin{array}{l}\text { 关 } \\
\text { 'บ } \\
\text { ம் }\end{array}$ & $\begin{array}{l}\text { označenie vrcholov mnohouholníka vel'kými } \\
\text { tlačenými písmenami } \\
\text { protil'ahlé a susedné strany } \\
\text { uhlopriečka } \\
\text { vlastnosti rovinných geometrických útvarov: } \\
\text { počet strán, počet vrcholov, dížky susedných } \\
\text { a protil'ahlých strán } \\
\text { kruh, kružnica, časti kružnice (kruhu) a ich } \\
\text { označovanie: polomer (r), priemer (d), stred } \\
\text { (S), rysovanie kružnice (kruhu): } \\
\text { dlízka strany trojuholníka, štvorca a obdížnika } \\
\text { rysovanie l'ubovol'ného trojuholníka } \\
\text { rysovanie trojuholníka, ak sú dané dížky jeho } \\
\text { strán } \\
\text { obvod štvorca, obdížnika a trojuholníka (na } \\
\text { propedeutickej úrovni) ako súčet dĺžok strán }\end{array}$ & $\begin{array}{l}\text { označit' vrcholy mnohouholníka (trojuholníka, } \\
\text { štvorca a obdížnika, štvoruholníka, } \\
\text { pät'uholníka, ...), } \\
\text { vyznačit' protil'ahlé i susedné strany štvorca } \\
\text { a obdližnika, } \\
\text { v štvorci a obdížniku vyznačit' uhlopriečky, } \\
\text { popísat' vlastnosti rovinných geometrických } \\
\text { útvarov (trojuholník, štvorec, obdížnik), } \\
\text { rozlišit', pomenovat' kruh a kružnicu, } \\
\text { určit', vyznačit' a pomenovat' v kružnici (kruhu) } \\
\text { stred, polomer, priemer, } \\
\text { narysovat' kružnicu (kruh) pomocou kružidla, } \\
\text { odmerat' dížky strán trojuholníka, štvorca, } \\
\text { obdížnika (s presnost'ou na milimetre), } \\
\text { narysovat' trojuholník a pomenovat' jeho } \\
\text { vrcholy, } \\
\text { vypočítat' obvod trojuholníka, štvorca } \\
\text { a obdížnika ako súčet dížok strán, }\end{array}$ \\
\hline
\end{tabular}

\section{METODOLÓGIA}

Našim ciel'om bolo navrhnút' aktivity a knim príslušné učebné pomôcky zamerané na geometrické tvary. Zamerali sme sa na rozlišovanie, pomenovanie a kreslenie rovinných a priestorových útvarov. Následne sme vybrané aktivity overili v praxi, a to u žiakov prvého stupňa Základnej školy $v$ Tešedíkovo a k nej príslušnom školskom klube detí. Sledovali sme, ako žiaci participujú pri realizovaní aktivít, ich záujem, grafický prejav a chyby, ktorých sa dopúštali. Ciel'om našej praktickej realizácie aktivít bolo zistit' aj úroveň schopností žiakov voblasti rozlišovania a pomenovania rovinných a priestorových geometrických útvarov, popisovania ich vlastností, určovania ich polohy v priestore, rysovania úsečiek, štvorca a obdĺžnika. V praxi bola využitá behaviorálna metóda pozorovanie, ktorá sa opierala na pozorovaní správania a pohotovosti žiakov a ich úrovne matematických poznatkov pri realizácii nami navrhnutých aktivít.

\section{Štruktúrované pozorovanie}

Pozorovanie môžeme stručne popísat' ako sledovanie činností l'udí, záznam (opis) tejto činnosti, jej analýzu a vyhodnotenie. Pod pojmom metóda pozorovania sa v pedagogickom výskume rozumie cielavedomé, plánovité a systematické vnímanie javov vprirodzených podmienkach, ktoré majú odhalit' pedagogické zákonitosti. Je jednou zo základných metód využívaných v kvalitatívnom výskume. Sledovanie činnosti ludí je však obyčajne zložité. Paralelne prebiehajú viaceré činnosti, prelínajú sa a vzájomne sa ovplyvňujú. V pozorovanej situácii je obyčajne viac aktérov, ktorí do nej vstupujú a vystupujú. Preto je vel'mi tažké pozorovat' realitu vcelku, komplexne. Naopak, je potrebné pozorovanie zamerat' užšie, koncentrovat' sa na menší výsek z reality, alebo na jej segmenty a tie sledovat' hlbšie, podrobnejšie a presnejšie. Je potrebné presne vymedzit' javy, na ktoré sa pozorovanie sústredí. Musia to byt' javy, ktoré je možné objektívne zachytit', registrovat' a numericky vyjadrit'. Pozorovanie, ktoré má tieto vlastnosti, nazývame štruktúrované (Gavora a kol., 2010). Štruktúrované pozorovanie je teda takým typom pozorovania, pri ktorom sú vopred určené a v pláne procesu pozorovania zachytené jednotlivé prvky skúmaného sociálneho procesu a tiež i stanovené znaky a ich kategórie. Výskumník používa určité kódovacie schémy, ktoré sú tvorené dopredu pripravenými kategóriami pre zaznamenávanie toho čo sa deje. Pre sledovanie činnosti žiakov pri implementovaní navrhnutých aktivít sme si vopred pripravili pozorovacie hárky, v ktorých sme si stanovili určité kategórie, ako napr. záujem žiaka o činnost', aktivita žiaka pri činnosti a pod. (tab. 2 - 4). Pozorovacie hárky boli prispôsobené každej z troch realizovaných aktivít vzhl'adom na plnenie stanovených cielov. Pozorovanie prebiehalo priamo, 
žiakov sme sledovali osobne. Počas pozorovania sme boli v triede umiestnení tak, aby sme čo najmenej rušili respondentov počas činnosti na vyučovacej hodine.

\section{Návrh aktivít}

Obsah vzdelávania matematiky na prvom stupni základných škôl by mal nadväzovat' na poznatky žiakov, s ktorými prichádzajú z materských škôl. Tieto poznatky však naisto nebudú u žiakov v triede rovnaké, nakol'ko na Slovensku v tomto čase nie je povinná predškolská dochádzka detí a ani tá by nezaručila rovnaké poznatky žiakov o geometrických tvaroch. Je preto na učitel'ovi, aby sa tieto nezrovnalosti snažil vyrovnat' tak, aby sa šikovnejší žiaci „nenudili“ a tí slabší mali možnost' v čo najkratšom čase „dobehnút“" svojich spolužiakov. Ked’že učenie matematiky by malo byt' pre žiakov aj zaujímavé, zamerali sme sa v aktivitách aj na hrovú činnost'.

\begin{abstract}
Aktivita „Šarkan“
Obsahový štandard: geometrické útvary kruh, štvorec, trojuholník, obdížnik.

Výkonový štandard: rozlíšit, dokreslit' a umiestnit' rovinné geometrické útvary podl'a pokynov.

Didaktický ciel: Ciel'om aktivity je rozlišovanie rovinných geometrických útvarov, ich dokresl'ovanie a umiestňovanie v požadovanom poradí, rozvoj jemnej motoriky.

Veková kategória: 6-7 rokov

Organizácia: individuálna

Pomôcky: pracovný list (obr. 1), ceruzka, farbičky

Postup: Žiakom dáme k dispozícii jeden pracovný list. Na ňom je znázornený šarkan schvostom ozdobeným rovinnými geometrickými útvarmi, ktorý treba dokončit'. Postupnost' útvarov je nasledovný - kruh, štvorec, trojuholník, obdlžnik. Ked' bude postupnost' útvarov hotová, zhodné útvary vyfarbia rovnakou farbou (kruh červenou, štvorec žltou, trojuholník modrou a obdížnik zelenou farbou).

Poznámka: Didaktickú aktivitu môžeme využit' aj vobdobí šarkaniád na spestrenie vyučovacej hodiny geometrie.
\end{abstract}

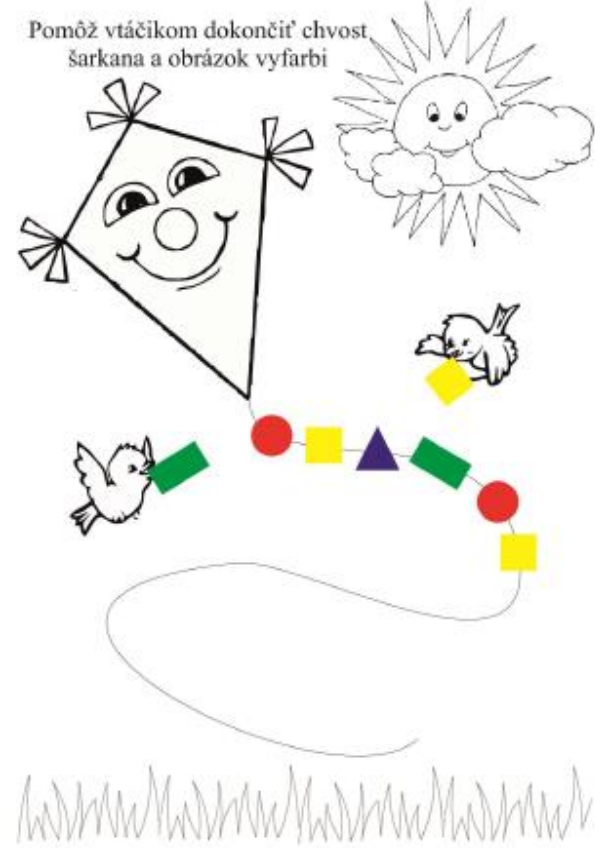

obr. 1

\section{Aktivita „Hádaj, aký útvar som“}

Obsahový štandard: rovinné geometrické útvary (kruh, trojuholník, štvorec a obdĺžnik)

Výkonový štandard: rozlišsit', pomenovat' rovinné geometrické útvary

Didaktický ciel': Ciel'om aktivity je poznat', rozlišovat' a pomenovat' rovinné geometrické útvary.

Veková kategória: 6-7 rokov

Organizácia: frontálna

Pomôcky: rovinné geometrické útvary z tvrdého papiera (obr. 2)

Postup: Postupné odkrývanie útvarov. Čo to môže byt' - trojuholník, štvoruholník, štvorec, obdĺžnik, kruh. Odkrývaním sa spresňuje predstava o danom útvare.

Poznámka: Geometrické útvary musia byt' primeranej vel'kosti, aby bolo dostatočne možné vidiet' aj zo zadných lavíc triedy.
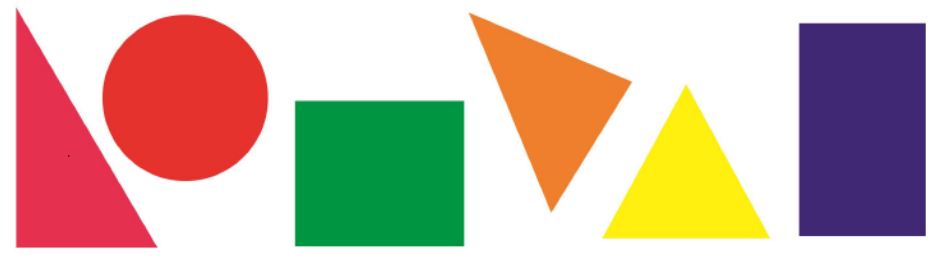

Obr. 2

\section{Aktivita „Môj vysnívaný dom“}

Obsahový štandard: rysovanie štvorca a obdľžnika v štvorcovej sieti

Výkonový štandard: vyznačit protil'ahlé i susedné strany štvorca a obdľžnika

Didaktický ciel': Ciel'om aktivity je vyznačit' protil'ahlé i susedné strany štvorca a obdĺžnika, precvičit' rysovanie kolmíc, rozvoj fantázie, tvorivosti a jemnej motoriky. 
Veková kategória: 9-10 rokov

Organizácia: individuálna

Pomôcky: čistý papier, pravítko s ryskou, ostrá ceruzka, príp. guma

Postup: Pred rysovaním rovinných geometrických útvarov štvorca a obdížnika je potrebné precvičit' rysovanie kolmíc a prácu s pravítkom s ryskou. Žiakov môžeme do činnosti motivovat' názornou ukážkou pravého pôdorysu domu, ktorú vytvorili stavební inžinieri. Úlohou žiakov bude narysovat' pôdorys ich vysnívaného domu.

Poznámka: Ak žiaci stihnú, na záver môžu jednotlivé izby zariadit' nábytkom.

\section{Aktivita „Pexeso“}

Obsahový štandard: vlastnosti rovinných geometrických útvarov: počet strán, počet vrcholov, dížky susedných a protil'ahlých strán.

Výkonový štandard: popísat' vlastnosti rovinných geometrických útvarov.

Didaktický ciel: Ciel'om aktivity je popísat' vlastnosti rovinných geometrický útvarov.

Veková kategória: 8-10 rokov

Organizácia: vo dvojiciach

Pomôcky: kartičky pexeso (obr. 3)

Postup: Kartičky sú pomiešané na stole tak, aby boli otočené zadnou stranou hore. Na jednej kartičke je zospodu text o vlastnostiach rovinného geometrického útvaru a na druhej kartičke je obrázok daného útvaru. Žiak otáča vždy po dve kartičky, zistujue, či čítané vlastnosti patria danému obrázku. Ak áno, dvojicu kartičiek odloží bokom a otočí d’alšie dve kartičky. Ak nie, kartičky otočí naspät' a na rade je d'alší hráč. Hra pokračuje, kým sa nenájdu všetky správne dvojice kartičiek. Vítazom sa stáva ten, kto počas hry našiel najviac správnych dvojíc kartičiek.

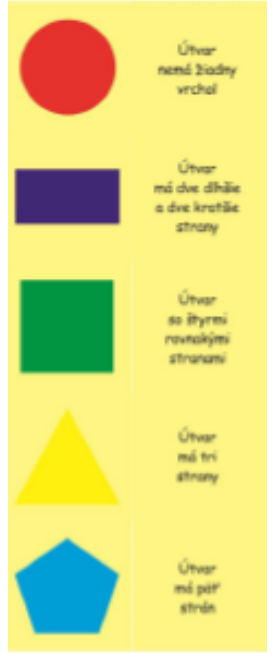

Obr. 3

\section{Aktivita „Geometrický vesmír“}

Obsahový štandard: rovinné a priestorové geometrické útvary

Výkonový štandard: rozlišovat' a pomenovat' rovinné geometrické útvary kruh, štvorec, obdížnik, trojuholník; priestorové geometrické útvary: kocka, valec

Didaktický ciel': Ciel'om aktivity je rozlišovat' a pomenovat' rovinné geometrické útvary kruh, štvorec, obdĺ̌nik, trojuholník; priestorové geometrické útvary: kocka, valec; rozvoj fantázie, tvorivosti a jemnej motoriky

Veková kategória: 6-10

Organizácia: skupinová, maximálne 6 hráči

Pomôcky: hracie pole (obr. 4), kocka (obr. 5), figúrky

Postup: Cesta na hracom poli je daná rôznymi rovinnými a priestorovými geometrickými útvarmi. K hre je potrebná hracia kocka, ktorá zobrazuje dané geometrické útvary - štvorec, obdĺžnik, trojuholník, kruh, kocka, valec. Úlohou žiakov je hodit' kockou, pomenovat' hodený útvar a postavit' sa na najbližšie pole zobrazujúce tento útvar. Podstatou hry je čo najskôr sa dostat' zo štartového pol'a do ciel'ového. Kto sa tam prvý dostane, vyhráva prvé miesto. Hra pokračuje, kým sa všetci hráči dostanú do ciela.

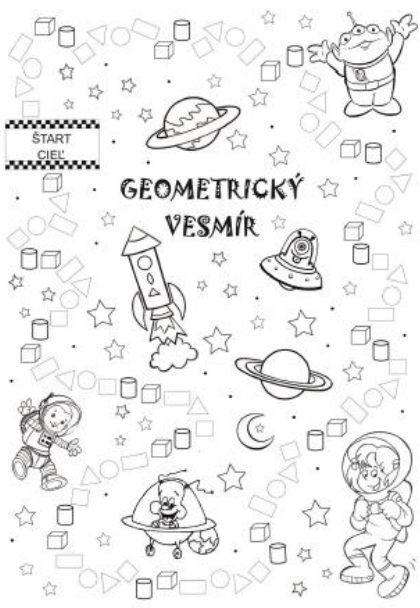

obr. 4

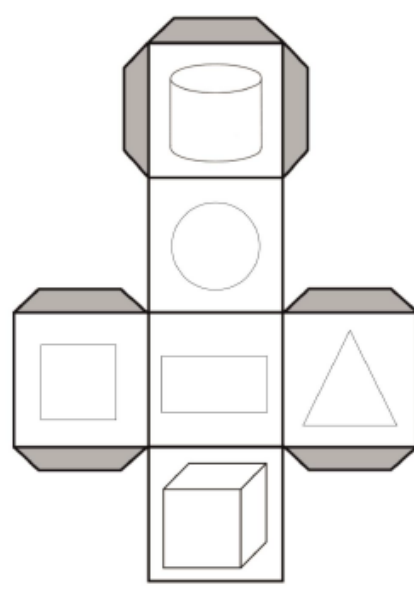

obr. 5 
Aktivita „Kvarteto“

Obsahový štandard: rovinné a priestorové geometrické útvary

Výkonový štandard: rozlišovat’ a pomenovat' rovinné geometrické útvary kruh, štvorec, obdížnik, trojuholník; priestorové geometrické útvary: kocka, valec

Didaktický ciel': Ciel'om aktivity je rozlišovat' a pomenovat' rovinné geometrické útvary kruh, štvorec, obdĺžnik, trojuholník; priestorové geometrické útvary: kocka, valec a v hre k nim priradit' vhodné písmená

Veková kategória: 6-10 rokov

Organizácia: skupinová, minimálne 2 hráči, ideálne 4 hráči

Pomôcky: karty kvarteto (obr. 6)

Postup: Karty kvarteta obsahujú 8 skupín kariet, pričom každá skupina zobrazuje určitý rovinný alebo priestorový geometrický útvar (štvorec, obdížnik, kruh, trojuholník, pätuholník, kocka, valec, gul'a). Skupiny určitých útvarov zobrazujú ten istý útvar a jednotlivé karty skupiny sú ešte označené písmenami $A, B, C$ a $D$. Napr. skupina kariet so štvorcom obsahuje karty: štvorec $A$, štvorec $B$, štvorec $C$ a štvorec $D$. Ciel'om hry je získat' čo najviac kompletných štvoríc kariet podla vlastného výberu žiaka. Začínajúci hráč požiada iného hráča o kartu, o ktorú má záujem. Ak tú kartu má, musí mu ju dat', ak nemá, začínajúci hráč si berie zo stredovej kopy kartu a pokračuje hráč, ktorý danú kartu nemal. Ak hráč získal kompletnú zbierku štvorice kariet daného geometrického útvaru, môže si ju odložit' bokom. Výhercom je hráč, ktorý má najviac úplne spárovaných skupín kariet.

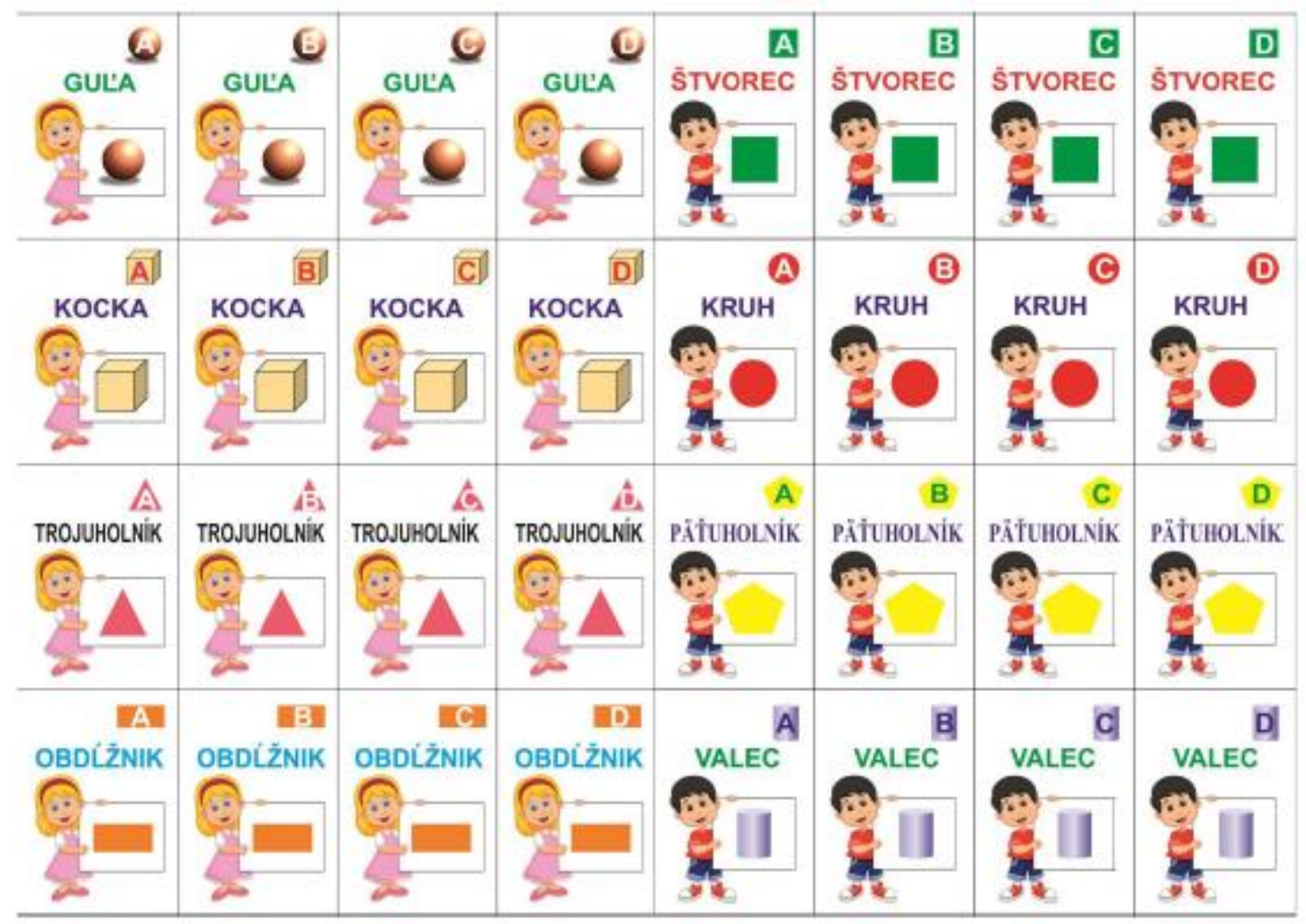

Obr.6

\section{VYHODNOTENIE}

\section{Aktivita Šarkan}

Aktivitu sme zrealizovali v prvej triede základnej školy, ktorá bola prislúchajúca danej vekovej kategórii 6 až 7 rokov. Organizačne bola uskutočnená individuálne, teda každý žiak triedy pracoval samostatne na vlastnom pracovnom liste. K pracovnému listu potrebovali žiaci farebné ceruzky. Ciel'om tejto aktivity bolo precvičovanie rozlišovania a pomenovania rovinných geometrických útvarov, zdokonal'ovanie $v$ ich kreslení a schopnost' pokračovat' v začatej postupnosti rovinných útvarov. Na realizácii didaktickej aktivity sa zúčastnilo 13 žiakov. Pred prácou na pracovnom liste sme si zopakovali, aké rovinné geometrické útvary sú na ňom znázornené. Upozornili sme ich, že každý rovinný geometrický útvar má svoju farbu a miesto, poradie. Pre overenie, že žiaci úlohe porozumeli, sme si nahlas povedali, aké rovinné geometrické útvary budú na chvoste nasledovat'. 
Žiaci naše pokyny počúvali a prejavovali záujem o realizovanú činnost'. Nakol'ko našim pokynom vel'ká väčšina porozumela, úlohu plnili správne. Jeden žiak vyžadoval individuálny prístup, úlohu dokázal vyriešit' len s našou pomocou. Práce boli vel'mi úhladné. Iba v ojedinelých prípadoch boli práce vyfarbené neesteticky a sneprimeraným tlakom ceruzky na papier. Geometrické útvary rozlišovali všetci žiaci okrem spomenutého problémového žiaka. Z analýz hotových prác sme zistili, že väčšine žiakov nerobí problém pokračovat' v postupnosti rovinných geometrických útvarov správne. Stal sa aj taký prípad, kedy vpostupnosti nepokračoval správne, ale začal kreslit' od začiatku útvary $v$ danom poradí (obr. 7).

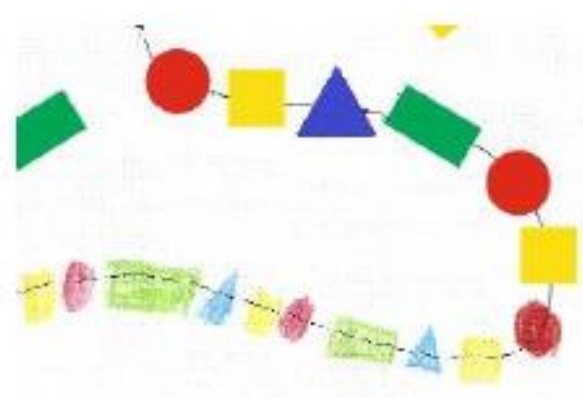

Obr. 7

Vel'kost' kreslených útvarov bola primeraná. Všeobecne môžeme povedat', že najväčšie problémy žiakom spôsobilo kreslenie útvarov štvorca a obdížnika. Ich tvar zamieňali, obdížnik mal tvar lichobežníka a štvorec bol roztiahnutý do tvaru obdížnika. Dodržat' poradie útvarov pre žiakov nebolo náročné. Na záver aktivity sme so zopakovali, aké útvary sme kreslili, útvary pomenovali správne. Poskytli sme im priestor na vyjadrenie svojho názoru a postoju $\mathrm{k}$ aktivite. Žiak, ktorý úlohu nezvládol, sa k nej vyjadril negatívne, nepáčilo sa mu, že musel útvary kreslit'.

\section{Aktivita Môj vysnívaný dom}

Danú aktivitu sme zrealizovali v štvrtej triede základnej školy, ktorej prislúcha veková kategória 9-10 rokov. Každý žiak triedy mal vlastný pracovný list, na ktorom pracoval samostatne. K pracovnému listu potrebovali žiaci rysovacie potreby, presnejšie trojuholníkové pravítko s ryskou a ceruzku. Ciel'om aktivity bolo precvičenie rysovania kolmíc, rozvoj tvorivosti a jemnej motoriky. Na realizácii tejto didaktickej aktivity sa zúčastnilo 12 žiakov štvrtej triedy. Pred začatím rysovania sme si zopakovali, čo je kolmica, akými pomôckami sa rysuje, ako pri rysovaní držia rysovacie pomôcky. Ako motiváciu a názornú ukážku sme im pripravili a prezentovali skutočný pôdorys stavby. Zvolili sme plán stavby obsahujúci kolmice, teda štvorce a obdížniky. Ich úlohou bolo použitím kolmíc narysovat' ich vysnívaný dom. Mohli sa inšpirovat' pôdorysom stavby vyvesenej na tabulu, domom, v ktorom žijú alebo uplatnením svojej fantázie vytvorit' vlastný plán stavby.

Pri vysvetl'ovaní pokynov $\mathrm{k}$ didaktickej aktivite bol jeden žiak spočiatku nepozorný a nepočúval, potom po objasnení úlohy však prejavil tiež záujem o činnost'. Pri pozorovaní žiakov pri činnosti sme si všimli, že niektorí žiaci nepoužívajú rysku na trojuholníkovom pravítku. Väčšina žiakov používala rysku na pravítku správne, vyznačovali ňou protil'ahlé a susedné strany štvorca a obdížnika. S technikou držania rysovacích potrieb nemali žiaci táǎkosti. Vel'ký počet žiakov k rysovaniu pôdorysu domu využíval vlastnú fantáziu a tvorivost', vytvárali jedinečné práce. Iba jeden žiak sa inšpiroval prezentovanou názornou ukážkou práce. Pri rysovaní vykonávali dostatočný tlak ceruzky na papier, ojedinele bol tento tlak až vel'ký. Z toho vyplýva aj estetická úhl'adnost́ prác, v ktorej bola zastúpená väčšina prác.

\section{Aktivita Geometrická vesmír}

Túto aktivitu sme zrealizovali v školskom klube detí prislúchajúcej k základnej škole. Žiakom navštevujúcich ŠKD prislúcha veková kategória 6-10 rokov. Aktivita bola organizačne realizovaná skupinovo. Realizáciu sme rozčlenili na dve časti. Prvá čast' predstavovala činnost' v rámci esteticko-výchovnej oblasti výchovy - vyfarbenie hracieho plánu. Druhá čast́ nám slúžila vo vzdelávacej oblasti výchovy ako didaktická hra. K didaktickej hre potrebovali žiaci okrem hracieho plánu kocku zobrazujúcu rovinné a priestorové geometrické útvary (štvorec, trojuholník, kruh, obdížnik, kocka, valec) a figúrky. Ciel'om aktivity bolo precvičenie rozlišovania a pomenovávania rovinných a priestorových geometrických útvarov a na základe toho sa pohybovat' po hracom poli, rozvoj fantázie, tvorivosti a jemnej motoriky. Na realizácii didaktickej hry sa zúčastnilo 14 žiakov štyroch ročníkov prvého stupňa základnej školy. Na úvod sme im vysvetlili, ako bude daná činnost' prebiehat'. Počet žiakov navštevujúcich školský klub detí je vysoký, preto sme danú čast žiakov vyberali na zúčastnenie sa na realizácii aktivity podl'a ich záujmu. V prvej časti realizácie bola ich úlohou výtvarne vypracovat' hrací plán a hraciu kocku didaktickej hry pomocou farebných ceruziek. Zhodné geometrické útvary vyfarbili rovnakou farbou, obrázky vyfarbovali podl'a vlastnej fantázie a tvorivosti. Pozadie hracieho pola vyplnili použitím servítky potretou modrou kriedou. Hotové hracie pole d'alej použili na hru. Počas činnosti bola disciplína dobrá, výtvarná práca i hra ich bavila, navzájom sa pri nej nevyrušovali. 
Žiaci v oboch častiach realizácie počúvali pokyny, ktorým rozumeli a následne ich správne plnili. O dané činnosti prejavovali záujem, tešili sa z nej. Počas výtvarnej práce pracovali žiaci aktívne, boli sústredení a vyfarbovali sebavedome $s$ istotou. Jeden žiak bol spočiatku neistý v rozlišovaní geometrických útvarov, ktoré mal vyfarbit, a preto sa podriad'oval práci ostatných. S vyfarbením zhodných útvarov nemali žiaci problém, aj spomínaný žiak ich vyfarbil správne. Hracie pole vyfarbovali viacerí žiaci naraz, napriek tomu sa navzájom nerušili a rešpektovali spoločnú prácu. Výtvarné potreby držali a používali žiaci správne, pri práci neopravovali gumovaním. Zobrazené obrázky vyfarbovali žiaci podla vlastnej fantázie. O hru prejavili žiaci vel'ký záujem, boli nadšení, že sa mohli podiel'at' na vytvorení hracieho pol'a. Počas hry nepotrebovali pomoc, hrali sa nenútene. Zobrazené geometrické útvary na hracom poli a hracej kocke rozlišovali, pri ich pomenovaní však boli menšie nedostatky. U dvoch žiakov sa stalo, že zamieňali pomenovanie útvarov štvorca a kocky. Pravidlám sa podriad'ovala väčšina žiakov, jeden žiak sa pokúšal o podvádzanie. Žiaci prejavovali svoje emócie primeraným spôsobom, ojedinele sa žiaci vyjadrili hnevom z prehry.

\section{Celkové zhrnutie}

Didaktické aktivity realizované hrovou formu majú svoj výchovno-vzdelávací ciel', pričom si ho žiak často neuvedomuje. Cielom našej praktickej realizácie aktivít bolo zistit́ úroveň schopností žiakov voblasti rozlišovania a pomenovania rovinných a priestorových geometrických útvarov. Vo všeobecnosti sme spozorovali, že väčšina žiakov úlohu splnila v plnej miere. Ťažkosti boli najčastejšie prítomné pri rozlišovaní a kreslení útvaru obdížnika a štvorca. Ich pomenovania často zamieňalo.. Zo záverečných rozhovorov vyplynulo, že žiaci uprednostňujú takého typy aktivít na vyučovacej hodine geometrie pred tradičnými formami práce. Vyjadrili svoj záujem o d’alšiu prácu na didaktických aktivitách. Počas realizácie nami navrhnutých didaktických aktivít sme získali rôzne skúsenosti. Predpokladali sme, že takýto spôsob práce na vyučovacej hodine je pre žiakov viac prítažliví ako tradičná forma práce a úloh. Naše predpoklady sa potvrdili a na základe pozorovania sme skonštatovali, že hrová forma práce má pozitívny vplyv na motiváciu žiakov, ich záujem o nové vedomosti rastie, utvrdzujú sa už získané znalosti, a tým rastie aj záujem o predmet matematika. Vd'aka aktivite "Môj vysnívaný dom" sme v niektorých žiakoch prebudili záujem o architektúru, čo považujeme za prínosné. Boli nadšení, že si mohli navrhnút vlastný dom a zariadit' ho podla ich individuálnych predstáv, fantázie a tvorivosti.

\section{ZÁVER}

V procese vyučovania je často málo času na realizovanie rôznych zaujímavých aktivít na rozvoj geometrických predstáv. Preto sme sa rozhodli navrhnút aj také aktivity, ktoré sa môžu realizovat' i mimo vyučovania, napr. v školských kluboch detí Veríme, že tieto aktivity môžu zatraktívnit́ vyučovanie geometrie na prvom stupni základnej školy, a tak zlahčit prácu začínajúcich i skúsenejších pedagógov či vychovávatelov. Súhlasíme s Brinckovou (2001), že na rozpoznanie chýb geometrického myslenia žiakov v mladšom školskom veku je vhodné zaradit' hrové aktivity.

\section{Pod'akovanie}

Príspevok vznikol v rámci projektu KEGA 016UKF - 4/2016 Implementácia konštruktivisticky orientovaného vyučovania matematiky s dôrazom na aktívne nadobúdanie poznatkov žiakmi v kontexte bilingválneho vzdelávania.

\section{Literatúra}

[1] Boroš, J. (2002). Úvod do psychológie. Bratislava: Iris, 2002. 305 s. ISBN 80-8901-835-1

[2] Brincková, J. (2001). Tvorivé dielne 2 zamerané na didaktické hry v geometrii Ž̌. Banská Bystrica: UMB v Banskej Bystrici, 2001. 42 s. ISBN 80-8055-526-5.

[3] Bugárová, M. (2016) Geometrické tvary v primárnom vzdelávaní. Diplomová práca. Nitra: UKF v Nitre, 2016. $66 \mathrm{~s}$.

[4] Čáp, J. (1980). Psychologie pro učitele. Praha: SPN, 1980. 384 s.

[5] Gavora, Peter a kol. (2010). Elektronická učebnica pedagogického výskumu. Bratislava: Univerzita Komenského, 2010. Dostupné na: http://www.e-metodologia.fedu.uniba.sk/ISBN 978-80-223-2951-4.

[6] Jakabčic, I. (2002) Základy vývinovej psychológie. Bratislava: Iris, 2002. 83 s. ISBN 80-89018-34-3. 
[7] Jurčo, M. (1964). Rozumový vývin detí a mladistvých. In Problémy psychológie dietatáa a mládeže. Bratislava: SPN, 1964. s. 99-106.

[8] Jurišová, E. (2013). Vybrané kapitoly z ontogenetickej psychológie - všeobecná, teoretická čast'. Nitra : UKF, 2013. 110 s. ISBN 978-80-558-0305-0.

[9] Molnár, J. (2009) Rozvijení prostorové predstavivosti (nejen) ve stereometrii. Olomouc: Univerzita Palackého v Olomouci, 2009. 144 s. 978-80-2442-254-1

[10] Popperová, M. (1964). Riadenie procesu vývinu predstáv u žiakov 5. ročníka. In Problémy psychológie diet'at'a a mládeže. Bratislava : SPN, 1964. s. 122-127.

[11] Šedivý, O. (2005). Vyučovanie stereometrie a rozvoj predstavivosti. In. Rozvíjanie priestorovej a geometrickej predstavivosti. Nitra : UKF, 2005. ISBN 80-8050-863-1, s. 3-9.

[12] Šmahovská, J. (2014). Úlohy na rozvoj geometrickej predstavivosti žiakov mladšieho školského veku. In Naša škola. ISSN 1335-2733, 2014, roč. 18, č. 6-7, s. 56-63.

[13] ŠPÚ. (2015). Štátny vzdelávací program pre 1. stupeň základnej školy v Slovenskej republike ISCED 1. Matematika - primárne vzdelávanie. Dostupné na: https://Ink.sk/azG0

[14] Understanding Van Hiele Levels for Geometry. Citované dňa 23. Októbra 2018. Dostupné na https://www.mathgiraffe.com/blog/understanding-van-hiele-levels-for-geometry

[15] Verkinová, A. (1998). Hra a tvorivost' v matematike v 2. ročníku základnej školy. In Naša škola. ISSN 13352733. 1998. roč. 2. č. 3. s. 20-23. 